\title{
EFEKTIVITAS PENEGAKAN HUKUM PERATURAN DAERAH KOTA PEKALONGAN NOMOR 19 TAHUN 2012 TENTANG KAWASAN TANPA ROKOK (Studi Terhadap Anggota Polri Polres Pekalongan Kota)
}

\author{
Da rod i \\ Magister Hukum Universitas Jenderal Soedirman
}

\begin{abstract}
The smoking behaviour is behaviour that is detrimental, not only for the individual who smokes but also for the people around the smoker who inhaled smoke. Loss could be from the health and economic side. This research aims: a. to analyse the effectiveness of the enforcement Regulations of the regional city of Pekalongan number 19 in 2012 About the area Without Smoking against members of the national police Polres Pekalongan town. $b$. to analyze obstacles in overcoming the habit of smoking for the members of the national police Polres Pekalongan city. This research is qualitative research in methods of sociological, juridical approach are analyzed qualitatively.

The results of the research the following applicable local law enegakan:P Pekalongan number 19 in 2012 About the area Without Smoking against members of the police and the city of Pekalongan Polres ineffective because there are still $25 \%$ of members of the national police of the city of Pekalongan Polres smokes while carrying out his service to the community, sanctions for offenders KTR only given verbally reprimand. Constraints in addressing smoking habit to members of the national police, is the town of Pekalongan Polres: rule of law, the magnitude of the sanctions is not comparable to the conditions of the community so that law enforcement against infringement of these rules does not run effectively and no one has ever given the application of sanctions in accordance with applicable local Pekalongan number 19 in 2012 About the area Without Smoking
\end{abstract}

Keywords: effectivity, law of enforcement, local regulations

Perilaku merokok merupakan perilaku yang merugikan, tidak hanya bagi individu yang merokok tetapi juga bagi orang-orang disekitar perokok yang ikut terhirup asap rokok. Kerugian yang ditimbulkan bisa dari sisi kesehatan dan ekonomi. Penelitian ini bertujuan: a. Untuk menganalisis efektivitas penegakan hukum Peraturan Daerah Kota Pekalongan Nomor 19 Tahun 2012 Tentang Kawasan Tanpa Rokok terhadap anggota Polri Polres Pekalongan Kota. b. Untuk menganalisis kendala dalam mengatasi kebiasaan merokok bagi anggota Polri Polres Pekalongan Kota.Penelitian ini merupakan penelitian kualitatif dengan metode pendekatan secara yuridis sosiologis, dianalisis secara kualitatif.

Hasil penelitian sebagai berikut :Penegakan hukum Peraturan Daerah Kota Pekalongan Nomor 19 Tahun 2012 Tentang Kawasan Tanpa Rokok terhadap anggota Polri Polres Pekalongan Kota tidak efektif karena masih ada 25\% anggota Polri Polres Pekalongan Kota merokok saat melaksanakan pelayanan kepada masyarakat, Sanksi bagi pelanggar KTR hanya diberi teguran secara lisan. Kendala dalam mengatasi kebiasaan merokok bagi anggota Polri Polres Pekalongan Kota, adalah: Aturan Hukum, besarnya sanksi tidak sebanding dengan kondisi masyarakat sehingga penegakan hukum terhadap pelanggaran aturan tersebut tidak berjalan efektif dan belum ada yang pernah diberikan penerapan sanksi sesuai ketentuan Peraturan Daerah Kota Pekalongan Nomor 19 Tahun 2012 Tentang Kawasan Tanpa Rokok.

Kata Kunci: efektivitas, penegakan hukum, peraturan daerah.

\section{PENDAHULUAN}

Kesehatan merupakan hak setiap orang. Salah satu penyebabnya masalah kesehatan yaitu merokok. Perilaku merokok merupakan perilaku yang merugikan, tidak hanya bagi indivi- du yang merokok tetapi juga bagi orang-orang disekitar perokok yang ikut terhirup asap rokok. Kerugian yang ditimbulkan bisa dari sisi kesehatan dan ekonomi. 
Untuk menanggulangi jumlah penduduk yang tertimpa penyakit akibat merokok di Kota Pekalongan Jawa Tengah dikeluarkan Peraturan Daerah Kota Pekalongan Nomor 19 Tahun 2012 Tentang Kawasan Tanpa Rokok. Peraturan Daerah Kota Pekalongan Nomor 19 Tahun 2012 Tentang Kawasan Tanpa Rokok penetapan Kawasan Tanpa Rokok bertujuan untuk memberikan perlindungan dari bahaya asap rokok bagi perokok aktif dan/atau perokok pasif mengingat semakin meningkatnya jumlah perokok, terutama di kalangan anak usia remaja atau anak sekolah, bahkan mereka merokok di sembarang tempat, menjadi keprihatinkan.

Berdasarkan Peraturan Daerah Kota Pekalongan Nomor 19 Tahun 2012 Tentang Kawasan Tanpa Rokok penetapan Kawasan Tanpa Rokok bertujuan untuk : (a) Memberikan perlindungan dari bahaya asap rokok bagi perokok aktif dan/atau perokok pasif; (b) Memberikan ruang dan lingkungan yang bersih dan sehat bagi masyarakat; (c) Melindungi kesehatan masyarakat secara umum dan dampak buruk merokok baik langsung maupun tidak langsung; (d) Menciptakan lingkungan yang bersih dan sehat, bebas dari asap rokok; (e) Meningkatkan kesejahteraan masyarakat; (f) Mencegah perokok pemula.

\section{PERUMUSAN MASALAH}

Berdasarkan latar belakang di atas, dirumuskan permasalahan tersebut sebagai berikut, pertama, bagaimana efektivitas penegakan hukum Peraturan Daerah Kota Pekalongan Nomor 19 Tahun 2012 Tentang Kawasan Tanpa Rokok terhadap anggota Polri Polres
Pekalongan Kota; kedua, bagaimanakah kendala dalam mengatasi kebiasaan merokok bagi anggota Polri Polres Pekalongan Kota

\section{METODE PENELITIAN}

Penelitian ini merupakan penelitian kualitatif dengan metode pendekatan secara yuridis sosiologis. Spesifikasi yang dipergunakan dalam penelitian ini adalah penelitian secara dekriptif. ${ }^{1}$ Sumber Data adalah: a. Data Sekunder dalam penelitian ini bersumber dari peraturan perundang-undangan, yang mendukung penelitian ini. b. Data Primer dalam penelitian ini berupa hasil wawancara dengan Pejabat Kantor Kepolisian Resor Pekalongan Kota, anggota Polri Kepolisian Resor Pekalongan Kota serta pihak lain yang dirasa perlu dan ada relevansinya dengan masalah penelitian ini $^{2}$

\section{PEMBAHASAN}

Efektivitas penegakan hukum Peraturan Daerah Kota Pekalongan Nomor 19 Tahun 2012 Tentang Kawasan Tanpa Rokok terhadap anggota Polri Polres Pekalongan Kota

Untuk meningkatkan derajat kesehatan masyarakat Kota Pekalongan, diperlukan pengetahuan, pemahaman, kesadaran, kemauan, dan kemampuan masyarakat untuk senantiasa membiasakan hidup sehat, dalam menghadapi masalah tersebut adalah dengan membuat produk hukum berupa Peraturan Daerah Kota Pekalongan Nomor 19 Tahun 2012 Tentang Kawasan Tanpa Rokok, selanjutnya disingkat Perda Kota Pekalongan tentang KTR.

Menurut Soerjono Soekanto, suatu hukum dapat dikataka efektif apabila: (1) Dapat menca- 
pai tujuan yang telah dikehendaki, terutama pembentuk hukum serta pelaksana; (2) Hukum efektif apabila di dalam masyarakat, warganya berperilaku sesuai dengan apa yang telah dikehendaki oleh hukum.

Efektivitas hukum menyoroti tentang bagaimana suatu peraturan yang dibentuk untuk mencapai tujuan yang diinginkan, sehingga untuk mengukur efektivitas dari suatu peraturan dilihat dari keberhasilan pencapaian tujuan yang diinginkan. Jika peraturan tersebut telah mencapai tujuannya, maka peraturan tersebut dapat dikatakan efektif, begitu pula sebaliknya.

Berdasarkan Pasal 3 Peraturan Daerah Kota Pekalongan Nomor 19 Tahun 2012 Tentang Kawasan Tanpa Rokok penetapan Kawasan Tanpa Rokok bertujuan untuk : (a) Memberikan perlindungan dari bahaya asap rokok bagi perokok aktif dan/atau perokok pasif; (b) Memberikan ruang dan lingkungan yang bersih dan sehat bagi masyarakat; (c) Melindungi kesehatan masyarakat secara umum dan dampak buruk merokok baik langsung maupun tidak langsung; (d) Menciptakan lingkungan yang bersih dan sehat, bebas dari asap rokok; (e) Meningkatkan kesejahteraan masyarakat; (f) Mencegah perokok pemula.

Pasal 4 ayat (1) Peraturan Daerah Kota Pekalongan Nomor 19 Tahun 2012 Tentang Kawasan Tanpa Rokok penetapan Kawasan Tanpa Rokok merumuskan bahwa setiap orang berhak mendapat informasi mengenai Kawasan Tanpa Rokok. Pasal 5 Peraturan Daerah Kota Pekalongan Nomor 19 Tahun 2012 merumuskan sebagai berikut:

(1) Setiap orang wajib tidak merokok di tempat atau area yang dinyatakan sebagai Kawasan Tanpa Rokok.

(2) Setiap orang, lembaga dan/atau badan wajib tidak memproduksi, menjual, mengiklankan dan/atau mempromosikan rokok di tempat atau area yang dinyatakan sebagai Kawasan Tanpa Rokok

Sanksi bagi pelanggar KTR berdasarkan Pasal 27 Peraturan Daerah Kota Pekalongan Nomor 19 Tahun 2012 Tentang Kawasan Tanpa Rokok :

(1) Setiap orang yang melanggar ketentuan sebagaimana dimaksud dalam Pasal 5, dikenakan pidana denda paling banyak Rp. 50.000.000,00 (lima puluh juta rupiah) untuk setiap kali pelanggaran.

(2) Setiap pimpinan lembaga dan/atau badan pada Kawasan Tanpa Rokok yang tidak memenuhi kewajiban sebagaimana dimaksud dalam Pasal 5 ayat (2), Pasal 6 ayat (1) ayat (2) dikenakan pidana denda paling banyak Rp. 50.000.000,00 (lima puluh juta rupiah).

(3) Tindak pidana sebagaimana dimaksud pada ayat (1) adalah pelanggaran

(4) Selain sanksi pidana sebagaimana dimaksud pada ayat (2), dapat dikenakan sanksi lainnya sesuai ketentuan peraturan perundang-undangan.

(5) Pidana denda sebagaimana dimaksud pada ayat (1) dan ayat (2) dibayarkan langsung ke Rekening Kas daerah setelah mendapatkan penetapan Pengadilan.

Berdasarkan beberapa informasi yang terkumpul, berupa wawancara dan pengamatan langsung dapat digambarkan bahwa fenomena yang terjadi terkait dengan upaya penerapan atau implementasi Perda Kota Pekalongan Nomor 19 Tahun 2012 tentang Kawasan Tanpa Rokok masyarakat sudah mengetahui adanya Perda Kota Pekalongan Nomor 19 Tahun 2012 tentang Kawasan Tanpa Rokok, namun masih ada ditemukan pelanggaran-pelanggaran, dikaitkan dengan pendapat Soerjono Soekanto tentang teori efektifitas, maka:

Pertama, Pelaksanaan tidak sesuai de- 
ngan tujuan Peraturan Daerah Kota Pekalongan No. 19 Tahun 2012 tentang Kawasan Tanpa Rokok (KTR) dimaksudkan untuk memberikan perlindungan kepada masyarakat dari bahaya asap rokok, memberi ruang dan lingkungan yang bersih bagi masyarakat, melindungi kesehatan masyarakat dari dampak buruk merokok, hal ini dapat dilihat masih ada $25 \%$ anggota Polri Polres Pekalongan Kota merokok saat melaksanakan pelayanan kepada masyarakat.

Kedua, Sanksi bagi pelanggar KTR berdasarkan Pasal 27 Peraturan Daerah Kota Pekalongan Nomor 19 Tahun 2012 Tentang Kawasan Tanpa Rokok cukup tegas yang diterima oleh pelanggar, namun sampai saat ini setiap anggota Polri yang melakukan pelanggaran KTR hanya diberi teguran secara lisan dan belum ada anggota Polri yang melanggar KTR dikenakan sanksi denda seperti ketentuan Pasal 27 Peraturan Daerah Kota Pekalongan Nomor 19 Tahun 2012 Tentang Kawasan Tanpa Rokok.

Ketiga, semua pimpinan di jajaran Polres Pekalongan Kota sudah memasang tanda-tanda dilarang merokok berupa pamflet, dan melarang setiap anggota Polri merokok di lokasi yang ditetapkan sebagai KTR dan telah menyediakan tempat khusus merokok bagi anggota Polri di jajaran Polres Pekalongan Kota sekitar 50\% sehingga masih ada $25 \%$ anggota Polri yang melanggar KTR.

\section{Kendala dalam mengatasi kebiasaan mero- kok bagi anggota Polri Polres Pekalongan Kota}

Kendala dan upaya mengatasi kebiasaan merokok bagi anggota Polri Polres Pekalongan Kota mengacu pada teori yang dikemukakan oleh Soerjono Soekanto bahwa pokoknya masalah tersebut sebenarnya terletak pada faktor-faktor yang mungkin mempengaruhinya. Faktor-faktor tersebut mempunyai arti yang netral sehingga dampak positif atau negatifnya terletak pada isi faktor-faktor tersebut. Adapun faktor-faktor dimaksud adalah faktor hukumnya sendiri (perundang-undangan), faktor penegak hukum, faktor sarana atau fasilitas yang mendukung, faktor masyarakat, faktor kebudayaan.

\section{Faktor hukumnya sendiri (perundang-un- dangan)}

Berdasarkan Peraturan Daerah Kota Pekalongan Nomor 19 Tahun 2012 Tentang Kawasan Tanpa Rokok penetapan Kawasan Tanpa Rokok Pasal 27 Ayat 1 dan 2 yaitu : Setiap orang yang melanggar ketentuan dalam Pasal 5, Pasal 6 Ayat (2) diancam dengan denda sebanyak-banyaknya Rp. 50.000 .000

Dalam Perda Kota Pekalongan Nomor 19 Tahun 2012 tentang Kawasan Tanpa Rokok telah diatur mengenai penetapan sanksi bagi pengguna tempat parkir dan juru parkir yang tidak menaati aturan tersebut. Pasal 27 Ayat 1 dan 2 Peraturan Daerah Kota Pekalongan Nomor 19 Tahun 2012 Tentang Kawasan Tanpa Rokok yaitu : Setiap orang yang melanggar ketentuan dalam Pasal 5, Pasal 6 Ayat (2) diancam dengan denda sebanyak- banyaknya Rp. 50.000.000, namun sampai saat ini belum ada yang pernah diberikan penerapan sanksi sebesar Rp. 50.000. Semuanya hanya sebatas diberikan teguran dan peringatan.

\section{Faktor penegak hukum}

Sumber daya manusia yakni petugaspetugas pelaksanaan penegakan hukum Peraturan Daerah Kota Pekalongan Nomor 19 Tahun 2012 Tentang Kawasan Tanpa Rokok. 
Eksistensi Satuan Polisi Pamong Praja yang ditentukan berdasarkan Pasal 2 huruf $e$ Peraturan Daerah Kota Pekalongan Nomor 5 Tahun 2005 Tentang Pembentukan, Kedudukan, Tugas, Fungsi Dan Susunan Organisasi Satuan Polisi Pamong Praja Kota Pekalongan, dengan tugas pokok: "menegakkan Perda dan menyelenggarakan ketertiban umum dan ketenteraman masyarakat serta perlindungan masyarakat". Sumber Daya Manusia Satuan Polisi Pamong Praja Kota Pekalongan masih sangat terbatas dan jika ada ditemukan pelanggaran maka hanya sebatas diberikan teguran dan pembinaan. Oleh karena keterbatasan Satpol PP.

\section{Faktor sarana atau fasilitas yang mendukung}

Sarana atau fasilitas merupakan segala sesuatu yang dapat dipakai sebagai alat yang dapat memberikan kemudahan dan kelancaran dalam mencapai maksud dan tujuan. Apabila maksud dan tujuannya adalah mengefektifkan Undang-Undang maka segala sarana dan fasilitas yang mendukung perlu disediakan sehingga pihak yang melaksanakan UndangUndang tersebut akan lebih mudah dan nyaman dengan sarana dan fasilitas yang memadai tersebut.

Dalam hal pengadaan tempat merokok yang berada di KTR ataupun terkait Polsek yang tidak mempunyai sarana untuk merokok, sampai saat ini ruangan khusus untuk perokok di Polsek Pekalongan Selatan belum ada sehingga para perokok masih merokok disembarang tempat.

\section{Faktor Masyarakat}

Masyarakat belum memiliki kesadaran dan sikap yang dapat membantu keberhasilan kebijakan yang dibuat

\section{Faktor kebudayaan}

Menurut Friedman, budaya hukum pada hakikatnya merupakan salah satu komponen yang membentuk suatu sistem hukum. Karena merupakan salah satu komponen dari sistem hukum, maka keberadaannya sangat penting dan menentukan. Budaya hukum merupakan komponen yang terdiri dari nilai-nilai dan sikapsikap yang merupakan pengikat sistem serta menentukan tempat sistem hukum itu di tengahtengah kultur bangsa secara keseluruhan ${ }^{3}$

Budaya hukum masyarakat di daerah sekitar Pekalongan Kota yang berkaitan keadaaan hukumnya anggota Polri Kepolisian Resor Pekalongan Kota berdasarkan budaya hukum internal masih lemah.

\section{PENUTUP}

\section{Simpulan}

Berdasarkan hasil penelitian dan pembahasan maka dapat diambil simpulan sebagai berikut : pertama, Penegakan hukum Peraturan Daerah Kota Pekalongan Nomor 19 Tahun 2012 Tentang Kawasan Tanpa Rokok terhadap anggota Polri Polres Pekalongan Kota tidak efektif karena masih ada $25 \%$ anggota Polri Polres Pekalongan Kota merokok saat melaksanakan pelayanan kepada masyarakat, Sanksi bagi pelanggar KTR hanya diberi teguran secara lisan. Namun begitu semua pimpinan di jajaran Polres Pekalongan Kota sudah memasang 
tanda-tanda dilarang merokok berupa pamflet, dan melarang setiap anggota Polri merokok di lokasi yang ditetapkan sebagai KTR.

Kedua, Kendala dalam mengatasi kebiasaan merokok bagi anggota Polri Polres Pekalongan Kota: (1) Aturan Hukum, besarnya sanksi tidak sebanding dengan kondisi masyarakat sehingga penegakan hukum terhadap pelanggaran aturan tersebut tidak berjalan efektif dan belum ada yang pernah diberikan penerapan sanksi sesuai ketentuan Peraturan Daerah Kota Pekalongan Nomor 19 Tahun 2012 Tentang Kawasan Tanpa Rokok; (2) Sumber Daya Manusia Satuan Polisi Pamong Praja Kota Pekalongan masih sangat terbatas dan jika ada ditemukan pelanggaran maka hanya sebatas diberikan teguran dan pembinaan. Oleh karena keterbatasan Satpol PP; (3) Sarana dan prasarana yang dipergunakan untuk pelaksanaan Kawasan Tanpa Rokok masih belum memadai, seperti biaya operasi yang terbatas.

(4) Masyarakat belum memiliki kesadaran dan sikap yang dapat membantu keberhasilan kebijakan yang dibuat; (5) Budaya hukum masyarakat di daerah sekitar Pekalongan Kota yang berkaitan keadaaan hukumnya anggota Polri Kepolisian Resor Pekalongan Kota berdasarkan budaya hukum internal masih lemah.

\section{Saran}

Berdasarkan hasil penelitian responden pada umumnya sudah mengetahui tentang kawasan tanpa rokok. Namun, hal ini tidak menutup kemungkinan responden untuk tidak merokok di kawasan tanpa rokok. Salah satunya dikarenakan pengetahuan tentang kebijakan kawasan tanpa rokok masih rendah. Sikap responden terhadap penerapan kawasan tanpa rokok pada umumnya setuju dengan adanya peraturan tersebut. Tetapi, sebagian besar tidak setuju dengan adanya sanksi yang tegas jika ada yang merokok di kawasan tanpa rokok. Tindakan responden terhadap penerapan kawasan tanpa rokok pada umumnya masih kurang. Hal ini disebabkan masih tingginya prevalensi yang merokok di kawasan tanpa rokok. Padahal, sudah tentang kawasan tanpa rokok. Sebaiknya, anggota Polri dan masyarakat menaati peraturan kawasan tanpa rokok dan menghindari perilaku merokok. Bagi pemerintah agar meningkatkan sosialisasi tentang aturan tersebut, karena masih banyak masyarakat yang belum mengetahui tentang adanya kebijakan kawasan tanpa rokok.

\section{DAFTAR PUSTAKA}

Rahardjo, Satjipto, 1983 Hukum dan Perubahan Sosial, Suatu Tinjauan Teoritis serta Pengalaman-pengalaman di Indonesia, Alumni, Bandung

Bandung: Angkasa 1980. Hukum dan Masyarakat.

Ronny Hanitijo Soemitro,1985, Beberapa Masalah Dalam Studi Hukum Dan Masyarakat, Bandung Remadja Karya.

Roberia, 2012, Hak Atas Kesehatan dan Urgensi Proteksinya Dalam Rangka Kontinuitas Pembangunan Hukum Kesehatan, Jurnal Hukum Kesehatan: Vol. 4. NO. 6, Jakarta

Siti Maimunah, 2013, Cakupan Hak Asasi Manusia Bidang Kesehatan, Jurnal Hukum Kesehatan: Vol. 2. NO. 4.,Jakarta

Soekanto Soerjono, 1982. Kesadaran Hukum dan Kepatuhan Hukum, CV. Rajawali, Jakarta. 